\title{
EFEKTIVITAS PEMBELAJARAN MELALUI WHATSAPP GRUP TERHADAP KEMAMPUAN PEMECAHAN MASALAH MATEMATIKA
}

\author{
Siska Sagita Mustami*, Paridjo, Wikan Budi Utami \\ Universitas Pancasakti Tegal \\ e-mail: siskatami3@gmail.com*
}

\begin{abstract}
ABSTRAK
Penelitian ini bertujuan untuk mendeskripsikan rata-rata kemampuan pemecahan masalah peserta didik yang diajar menggunakan pembelajaran melalui WhatApp grup dapat mencapai KKM 77 serta melihat efektivitas pembelajaran melalui WhatsApp Grup dalam meningkatkan kemampuan pemecahan masalah matematika peserta didik. Jenis penelitian yang digunakan adalah ekspserimen. Populasi penelitian peserta didik kelas X MIA SMA Negeri 1 Ketanggungan kabupaten Brebes Tahun Pelajaran 2019/2020. Teknik sampling menggunakan cluster random sampling. Teknik analisis data menggunakan uji t satu sampel pihak kanan, uji Paired Sample T Test dan Uji N-Gain. Instrumen yang digunakan dalam penelitian ini adalah tes kemampuan pemecahan masalah matematika pada materi vektor dalam bentuk soal uraian berjumlah 6 item soal. Hasil penelitian menunjukkan bahwa rata-rata nilai kemampuan pemecahan masalah peserta didik yang diajar menggunakanpembelajaran melalui WhatsApp grup mencapai 77dan pembelajaran melalui WhatsApp Grup tidak efektif dalam meningkatkan kemampuan pemecahan masalah peserta didik. Pada nilai pembelajaran melalui WhatsApp grup (posttest) lebih kecil dari nilai pembelajaran luring (pretest) ini berarti peserta didik yang diajar menggunakan pembelajaran melalui WhatsApp grup (Posttest) tidak lebih baik dari pembelajaran luring (Pretest) dalam peningkatan kemampuan pemecahan masalah peserta didik, hal ini dikarenakan pada pembelajaran luring guru berinteraksi langsung dengan peserta didik sehingga terpantau seluruh kegiatan pembelajaran dibandingkan dengan WhatApp grup.
\end{abstract}

Kata kunci: efektivitas; kemampuan pemecahan masalah matematika; whatsapp grup

\section{PENDAHULUAN}

Pasca pengumuman resmi penetapan pandemik global Covid-19 oleh World Health Organization (WHO), negara-negara di dunia termasuk Indonesia menetapkan kebijakan pembatasan fisik dengan work from home and stay at home sebagai upaya mencegah penyebaran Covid-19. Dengan melihat situasi dan kondisi saat ini karena adanya wabah Coronavirus (COVID-19) yang di Indonesia sendiri mengumumkan adanya kasus ini dari maret 2020, tentu tidak dimungkinkan terjadi pembelajaran disekolah sehingga digunakan pembelajaran daring. Pembelajaran daring yang digunakan guru 
ialah WhatsApp grup. WhatsApp grup merupakan salah satu aplikasi chat yang digunakan untuk membantu peserta didik dalam proses pembelajaran dirumah.

Berdasarkan hasil observasi pada tanggal 15 Januari 2020 di SMA Negeri 1 Ketanggungan Kabupaten Brebes diperoleh informasi bahwa pada saat pembelajaran guru menggunakan model pembelajaran konvensional dengan metode ceramah, tanya jawab dan kelompok yang didalamnya meliputi antara lain pelatihan soal-soal, tugas harian dan ulangan harian. Sebagian peserta didik kurang antusias dan kurang aktif dalam proses pembelajaran dikelas. Hal ini menyebabkan kurang fokusnya peserta didik dalam kemampuan pemecahan masalah. Kemudian Kriteria Ketuntasan Minimal (KKM) yaitu 77.

Vektor merupakan salah satu pokok bahasan dari pelajaran matematika dalam jenjang menengah atas/sederajat. Disini peserta didik dituntut memahami konsep dan mampu untuk menyelesaikan permasalahan yang berkaitan dengan pokok bahasan vektor. Masalah yang dijumpai pada materi vektor, peserta didik masih bingung dan belum mengerti kegunaan vektor dikehidupan dan visualisasi vektor, sehingga mempengaruhi kemampuan pemecahan masalah matematis peserta didik. Oleh karena itu diperlukan video pembelajaran yang mampu merangsangsang pemahaman peserta didik sehingga kemampuan pemecahan masalah peserta didik dapat meningkat. Adapun indikator-indikator yang diperlukan untuk mengukur kemampuan pemecahan masalah matematis peserta didik. Sehingga, pemilihan vektor sebagai materi untuk penelitian.

Dengan demikian pembelajaran daring melalui WhatsApp grup dengan materi vektor diharapkan dapat membantu guru dalam proses pembelajaran, sehingga kemampuan pemecahan masalah yang diajarkan melalui pembelajaran daring dengan WhatsApp grup mencapai nilai rata-rata Kriteria Ketuntasan Minimal (KKM), dan apakah pembelajaran melalui WhatsApp Grup efektif dalam meningkatkan kemampuan pemecahan masalah peserta didik.

Hasil penelitian (Utomo, 2018) bahwa penerapan model pembelajaran berbasis masalah dengan menggunakan aplikasi WhatsApp berpengaruh atau berdampak positif yang ditunjukkan hasil belajar berada di atas kriteria capaian yang ditetapkan. Selain itu hasil penelitian (Iskandar, 2020) penggunaan grup WhatsApp sebagai media 
pembelajaran dirasa cukup membantu tutor dan peserta didik dalam proses pembelajaran sebagai pengembangan media pembelajaran. Demikian hasil penelitian (Pranajaya dan Hendra Wicaksono , 2018) menyatakan dalam proses belajar dengan aplikasi WhatsApp sangat bermanfaat, walaupun dalam pernyataannya penggunaan WhatsApp tidak sepenuhnya mempengaruhi nilai belajar.

Efektivitas adalah usaha untuk mencapai sasaran yang telah ditetapkan sesuai dengan kebutuhan, rencana, dengan menggunakan data, sarana, maupun waktu yang tersedia untuk memperoleh hasil yang maksimal baik secara kuantitatif maupun kualitatif (Supardi dalam Utami, dkk, 2018). Efektivitas adalah sesuatu kegiatan yang dapat diselesaikan dengan hasil sesuai atau mendekati dari apa yang direncanakan (Ma'mun, 2015: 14). Keefektifan dalam model pembelajaran adalah pengaruh yang dihasilkan dari proses pembelajaran baik dalam ketuntasan KKM, lebih baiknya model, maupun perbedaannya (Sholikhakh, dkk, 2019)

Berdasarkan beberapa pendapat diatas dapat disimpulkan bahwa Efektivitas adalah usaha untuk mencapai kegiatan proses pembelajaran yang dapat diselesaikan dengan hasil sesuai atau mendekati, baik ketuntasan KKM, lebih baiknya model maupun perbedaannya. Pembelajaran daring merupakan pemanfaatan jaringan internet dalam proses pembelajaran (Nakayama M, dkk, dalam Dewi, 2020)

Pembelajaran daring adalah pembelajaran yang menggunakan teknologi multimedia, kelas virtual, CD ROM, streaming video, pesan suara, email dan telepon konferensi, teks online animasi, dan video streaming online (Thorne dalam Kuntarto, 2017).

Pembelajaran daring bertujuan memberikan layanan pembelajaran bermutu dalam jaringan (daring) yang bersifat massif dan terbuka untuk menjangkau peminat yang lebih banyak dan lebih luas (Sofyana, 2019).

Sehingga dengan demikian, Pembelajaran daring adalah pemanfaatan jaringan internet dalam proses pembelajaran. Pembelajaran yang menggunakan teknologi multimedia, kelas virtual, CD ROM dan lain sebagainya. Tujuannya memberikan layanan pembelajaran bermutu dalam jaringan (daring) yang bersifat massif dan terbuka untuk 
menjangkau peminat yang lebih banyak dan lebih luas. Pada nilai Posttest menggunakan pembelajaran daring melalui WhatsApp Grup.

Aplikasi ini mempunyai fitur yang lengkap, cepat, mudah mengoperasikan, dan praktis hanya dengan menggunakan handphone. Aplikasi WhatsApp memiliki banyak fitur obrolan. Salah satu fitur tersebut adalah obrolan grup atau group chat. Fitur tersebut memungkinkan pengguna WhatsApp mengobrol dalam sebuah ruang obrolan yang biasa disebut sebagai grup. Jumlah maksimal anggota 250 pengguna. Obrolan grup dalam layanan WhatsApp dapat dibuat tanpa syarat, dan pembuat grup dapat menambahkan anggota hingga mencapai batas maksimal.(Utomo, 2018).

Indikator penggunaan WhatsApp dibagi menjadi 6, yaitu; grup WhatsApp untuk reuni, grup WhatsApp untuk diskusi, mengirim undangan acara, menelepon, berbagi lokasi, dan WhastApp Web. Adapun indikator penggunaan WhatsApp yang digunakan sebagai media pembelajaran dalam penelitian ini adalah grup WhatsApp untuk diskusi. Hal ini dapat dikategorikan pada indikator tersebut karena tidak tertutup kemungkinan terjadi diskusi dalam grup antara peserta didik dengan guru maupun antara peserta didik.(Rohmadi dalam Utomo, 2018).

WhatsApp secara efektif dapat memfasilitasi berbagai aktivitas sosial seseorang, baik individu atau kelompok, baik keluargaatau profesional. Aplikasi WhatsApp menawarkan sebuah pengalaman pesan instan yang ramah pengguna dan nyaman digunakan untukberagam konten dalam berbagai konteks. (Malka dalam Bafadhal, 2018).

Dengan demikian, WhatsApp grup adalah aplikasi yang dapat memfasilitasi berbagai aktivitas sosial seseorang melalui obrolan grup atau group chat dengan beranggotakan maksimal 250 dalam sebuah grup. Kelebihan WhatsApp Sebagai Media Pembelajaran adalah 1) WhatsApp tidak memerlukan sistem login setiap akan membuka bekerja, mirip seperti SMS yang menggunakan nomor telepon yang terdaftar pada ponsel pengguna, 2) segera terhubung dengan kontak pengguna: untuk memudahkan mendeteksi nomor ponsel yang sudah terdaftar pada WhatsApp, 3) pesan offline, whatsApp akan menyimpan pesan-pesan pengguna dan mengirimkannya kembali ketika pengguna menggunakannya kembali, sehingga pengguna tidak akan kehilangan 
pemberitahuan pesan baru atau pada saat mematikan telepon, 4) kelebihan lainya: pengguna dapat bertukar kontak, membagikan lokasi (share live location), email riwayat percakapan, atur wallpaper dan nada pemberitahuan khusus, juga kirim pesan ke beberapa kontak sekaligus (broadcast).

Kemudian Grup WhatsApp mempunyai kelebihan sebagai media pembelajaran, 1) pendidik dan peserta didik bisa bertanya jawab atau berdiskusi dengan lebih rileks tanpa harus terpusat pada pendidik seperti pembelajaran di kelas, yang sering menimbulkan rasa takut salah dan malu pada peserta didik, 2) dengan media WhatsApp, pendidik bisa berkreasi dalam memberikan materi maupun tugas tambahan kepada peserta didik, 3) peserta didik dengan mudah bisa mengirim balik hasil pekerjaan, baik berupa komentar langsung (chat group), gambar, video atau soft files lainnya yang berhubungan dengan pembelajaran, 3) dengan media WhatsApp, metode pembelajaran menjadi ramah lingkungan karena tidak lagi menggunakan hard copy (penggunaan kertas untuk mencetak atau menulis hasil pekerjaan peserta didik), 4) dengan media WhatsApp, dapat menjadi salah satu solusi pendidik untuk menyampaikan materi tambahan sebagai bahan pembelajaran di luar kelas.

Kekurangan WhatsApp sebagai media pembelajaran adalah 1) Pendidik dan peserta didik harus terhubung dengan layanan internet untuk mendapatkan informasi secara real times, 2) komunikasi menggunakan video, gambar dan file yang berukuran besar berpengaruh pada penggunaan data (biaya), 3) tanpa aturan atau kesepakatan yang jelas oleh admin (pendidik) grup, komunikasi dapat keluar dari kontek pembelajaran (Pustikayasa, 2019).

Faktor- faktor yang bisa mempengaruhi dalam menggunakan suatu produk, yang dimaksud adalah whatsapp. Faktor-faktor tersebut diantaranya 1) pengetahuan tentang karakteristik pengetahuan tersebut meliputi segala tentang whatsapp, versi, kemampuan, bagaimana cara mendownload dan menggunakannya, serta biaya yang dipakai untuk mengaksesnya, 2) manfaat harus tahu manfaat dari whatsapp itu sendiri seperti apa, keunggulan serta kelemahannya dibandingkan dengan aplikasi lainnya, 3) penggunaan disini lebih mengarah pada segi waktu, yaitu berapa lama whatsapp bisa 
digunakan jika tersambung dengan koneksi internet dan tujuan menggunakan whatsapp (Nitisusantro dalam Anjani, 2018)

Menurut KBBI Kemendikbud (2016) luring adalah akronim dari luar jaringan; terputus dari jejaring komputer. Kemudian pembelajaran adalah proses, cara, perbuatan menjadi belajar. Sehingga dapat disimpulkan bahwa pembelajaran luring adalah proses belajar dalam kondisi terputusnya jejaring komputer atau disebut juga luar jaringan. Pada nilai Pretest menggunakan pembelajaran luring.

Pemecahan masalah merupakan aspek yang sangat penting dalam proses belajar dan pengembangan matematika, sehingga pembelajaran matematika di sekolah seharusnya berfokus pada peningkatan kemampuan siswa dalam memecahkan masalah matematik yang meliputi aspek pengetahuan konseptual/prosedural, strategi, komunikasi, dan akurasi (AS Dewi, Isnani, \& Ahmadi, 2019).

Kemampuan pemecahan masalah adalah jantungnya matematika. Kemampuan pemecahan masalah harus dimiliki peserta didik untuk melatih agar terbiasa menghadapi berbagai permasalahan, baik masalah dalam matematika, masalah dalam bidang studi lain, atau masalah dalam kehidupan sehari-hari yang semakin kompleks (Branca dalam Effendi, 2012).

Pemecahan masalah merupakan sebuah proses di mana individu menggunakan, keterampilan, dan pemahaman yang telah diperoleh untuk menyelesaikan masalah situasi yang belum dikenalnya (Hendriana dkk, 2017).

Langkah-langkah untuk menyelesaikan masalah matematika adalah memahami masalah, merencanakan menyelesaikan masalah, melaksanakan rencana untuk menyelesaikan masalah dan memeriksa kembali jawaban. Pada tahapan memahami masalah (Understand the problem) masalah harus diyakini oleh peserta didik. Untuk menyakini suatu permasalahan dapat dilakukan dengan membaca berulang-ulang, menanyakan pada diri sendiri tentang apa yang ketahui, apa yang tidak diketahui, dan menanyakan tujuan dari permasalahan matematika tersebut. Tahapan ini memberikan pondasi bagi peserta didik untuk mampu melangkah pada tahap berikutnya yaitu merencanakan menyelesaikan masalah (make a plan), melaksanakan rencana untuk menyelesaikan masalah (carry out our plan) dan memeriksa kembali jawaban (look back at 
thecompleted solution). Jika peserta didik tidak mampu mengidentifikasi apa yang diketahui dan apa yang ditanyakan dari sebuah permasalahan maka ada kemungkinan peserta didik tersebut tidak mampu untuk menyelesaikan masalah yang dihadapinya (Polya dalam Widodo, 2015 : 128). Dengan demikian, dapat disimpulkan bahwa kemampuan pemecahan masalah adalah usaha untuk menyelesaikan masalah sehingga dapat memperoleh solusi atau penyelesaiannya.

\section{METODE PENELITIAN}

Dalam penelitian ini jenis penelitian yang digunakan adalah penelitian eksperimen. Desain penelitian yang digunakan adalah One-Group Pretest-Posttest Design. Penelitian ini dilakukan di SMA Negeri 1 Ketanggungan dengan populasi yang peserta didik kelas $\mathrm{X}$ MIA dan sampel penelitian ini adalah peserta didik kelas X MIA 3 sebanyak 36 peserta didik. Teknik pengambilan sampel yang digunakan adalah probability sampling dengan menggunakan teknik cluster random sampling (area acak sampel) artinya pengambilan anggota sampel berdasarkan daerah populasi yang telah ditetapkan. Probability sampling adalah teknik pengambilan sampel yang memberikan peluang sama bagi setiap unsur/anggota populasi untuk dipilih menjadi anggota sampel (Lestari, 2017).

Teknik pengumpulan data dengan menggunakan dokumentasi dan tes. Teknik pengumpulan data dokumentasi ini digunakan untuk mendapatkan data-data seperti daftar nama peserta didik, dan daftar nilai ulangan harian sebelum COVID-19 kelas X mata pelajaran matematika tahun pelajaran $2019 / 2020$. Tes adalah prosedur sistematik yang dibuat dalam bentuk tugas-tugas yang distandardisasikan dan diberikan kepada individu atau kelompok untuk dikerjakan, dijawab, atau direspon, baik dalam bentuk tertulis, lisan maupun perbuatan (Matondang, 2009). Teknik pengumpulan data tes ini digunakan untuk mengetahui kemampuan pemecahan masalah peserta didik yang berupa tes uraian materi vektor.

Teknik analisis data dalam penelitian ini adalah teknik analisis data sebelum penelitian, teknik analisis instrumen dan teknik analisis data setelah penelitian. Teknik analisis data sebelum dilakukan penelitian, perlu diuji kesetaraan sampelnya terlebih dahulu guna mengetahui apakah ada perbedaan kemampuan awal peserta didik. Teknik 
analisis intrumen tes diberikan kepada peserta didik dalam bentuk tes uraian guna mengumpulkan data dan diukur. Validasi intrumen tes kemampuan pemecahan masalah dengan menggunakan expert judment. Expert judgment yaitu pendapat para ahli melihat kesesuaian indikator dengan tujuan pengembangan instrumen, kesesuaian indikator dengan cakupan materi atau kesesuaian teori, melihat kesesuaian instrumen dengan indikator butir, melihat kebenaran konsep butir soal, melihat kebenaran isi, kebenaran kunci (pada tes), bahasa dan budaya dan teknik data setelah penelitian (Retnawati, 2015).

\section{HASIL PENELITIAN DAN PEMBAHASAN}

Berdasarkan hasil penelitian yang dilakukan di SMA Negeri 1 Ketanggungan Kabupaten Brebes pada peserta didik kelas X MIA Tahun Pelajaran 2019/2020 pada materi vektor menunjukan hasil yang berbeda antara peserta didik yang diajar dengan pembelajaran daring melalui WhatsApp grup.

Tabel 1. Hasil uji t satu sampel pihak kanan

\begin{tabular}{|c|c|c|c|c|c|c|}
\hline \multicolumn{7}{|c|}{ One-Sample Test } \\
\hline & \multicolumn{6}{|c|}{ Test Value $=77$} \\
\hline & \multirow[b]{2}{*}{$\mathrm{T}$} & \multirow[b]{2}{*}{ Df } & \multirow{2}{*}{$\begin{array}{l}\text { Sig. (2- } \\
\text { tailed) }\end{array}$} & \multirow{2}{*}{$\begin{array}{c}\text { Mean } \\
\text { Difference }\end{array}$} & \multicolumn{2}{|c|}{$\begin{array}{l}\text { 95\% Confidence Interval of } \\
\text { the Difference }\end{array}$} \\
\hline & & & & & Lower & Upper \\
\hline Nilai & 2,599 & 35 & ,014 & 4,111 & ,900 & 7,322 \\
\hline
\end{tabular}

Berdasarkan perhitungan uji t satu sampel pihak kanan tabel 1 diperoleh $t_{\text {hitung }}$ sebesar 2,599 dan karena $\mathrm{P}$-value $<0,05$ maka $H_{0}$ ditolak. Sehingga rata-rata nilai kemampuan pemecahan masalah peserta didik yang diajar menggunakan pembelajaran melalui WhatsApp grup mencapai 77. Dimana menurut hasil penelitian (Utomo, 2018 : 200) bahwa penerapan model pembelajaran berbasis masalah dengan menggunakan aplikasi WhatsApp berpengaruh atau berdampak positif yang ditunjukkan hasil belajar berada di atas kriteria capaian yang ditetapkan. 
Tabel 2. Hasil uji N-Gain

\begin{tabular}{|c|c|c|c|c|}
\hline \multicolumn{5}{|c|}{ Descriptives } \\
\hline & & & Statistic & $\begin{array}{l}\text { Std. } \\
\text { Error }\end{array}$ \\
\hline \multirow{13}{*}{$\begin{array}{l}\text { N_Gan_Score_Pers } \\
\text { en }\end{array}$} & Mean & & $-48,57$ & 21,52 \\
\hline & \multirow[t]{2}{*}{$\begin{array}{l}\text { 95\% Confidence } \\
\text { Interval for Mean }\end{array}$} & $\begin{array}{l}\text { Lower } \\
\text { Bound }\end{array}$ & $-92,41$ & \\
\hline & & $\begin{array}{l}\text { Upper } \\
\text { Bound }\end{array}$ & $-4,74$ & \\
\hline & 5\% Trimmed Mean & & $-34,67$ & \\
\hline & Median & & 3,33 & \\
\hline & Variance & & 15282,66 & \\
\hline & Std. Deviation & & 123,62306 & \\
\hline & Minimum & & $-433,33$ & \\
\hline & Maximum & & 87,50 & \\
\hline & Range & & 520,83 & \\
\hline & Interquartile Range & & 112,50 & \\
\hline & Skewness & & $-2,003$ & ,409 \\
\hline & Kurtosis & & 4,133 & 798 \\
\hline
\end{tabular}

Pada data tabel 2 diperoleh nilai rata-rata yaitu sebesar $-48,57$, kemudian kita masukan pada kategori tafsiran efektifitas N-Gain. Karena $-48,57<40$ maka pembelajaran menggunakan WhatsApp Grup masuk tafsiran tidak efektif. Sehingga pembelajaran menggunakan WhatsApp Grup tidak efektif dalam meningkatkan nilai kemampuan pemecahan masalah peserta didik.

Hal ini dikarenakan pada pembelajaran luring guru berinteraksi langsung dengan peserta didik sehingga terpantau seluruh kegiatan pembelajaran dibandingkan dengan WhatApp grup. Dimana sesuai dengan penelitian (Iskandar, 2020) dan (Pranajaya dan Hendra Wicaksono , 2018) yang menyatakan pembelajaran dirasa sangat membantu dalam proses pembelajaran dan aplikasi WhatsApp sangat bermanfaat, namun tidak sepenuhnya mempengaruhi nilai belajar.

Hambatan dalam penelitian ini antara lain kesulitan sinyal dikarenakan daerah peserta didik di SMA Negeri 1 Ketanggungan ada yang berada di selatan yang berdekatan dengan hutan, penggunaan kuota yang besar untuk mengunduh video, penyampaian materi dalam WhatsApp grup yang telah disampaikan dapat terjadi kekeliruan dalam memahami, pemahaman dari setiap peserta didik dengan apa yang disampaikan di dalam WhatsApp grup berbeda. Kemudian adanya peserta didik yang 
terlambat dalam pembahasan materi sehingga mengakibatkan kurang memahami materi yang disampaikan.

\section{KESIMPULAN}

Berdasarkan hasil analisis data yang telah diperoleh, maka dapat diambil kesimpulan bahwa rata-rata nilai kemampuan pemecahan masalah peserta didik yang diajar dengan pembelajaran melalui WhatsApp grup pada pokok materi vektor mencapai 77. Dan Pembelajaran menggunakan WhatsApp Grup tidak efektif dalam meningkatkan nilai kemampuan pemecahan masalah peserta didik. Kelebihan pembelajaran menggunakan whatsapp grup dalam penelitian ini yaitu: pendidik dan peserta didik bisa bertanya jawab atau berdiskusi tanpa harus terpusat pada pendidik seperti pembelajaran di kelas, yang sering menimbulkan rasa takut salah dan malu pada peserta didik. Dan Peserta didik dengan mudah bisa mengirimkan dan mengumpulkan hasil pekerjaannya. Kekurangan pembelajaran menggunakan whatsapp grup dalam penelitian ini yaitu : peserta didik menyediakan ruangan penyimpanan yang besar untuk mendapatkan video pembelajaran, dan ketertinggalan peserta didik dalam menyimak pembelajaran dalam grup whatsapp.

\section{SARAN}

Berdasarkan hasil penelitian, ada beberapa saran yang dapat penulis sampaikan antara lain dalam pembelajaran melalui WhatsApp grup, peserta didik mengalami yang namanya rasa jenuh, bosan dan malas. Guru lebih mempersiapkan lagi dalam pelajaran melalui pembelajaran melalui aplikasi WhatsApp grup yang dapat membantu proses pembelajaran dirumah sebagai alternatif dalam menghadapi pandemi COVID-19 atau jenis virus lainnya. Perlu diadakan pengembangan lanjutan dalam penelitian melalui pembelajaran melalui WhatsApp grup pada populasi, sampel dan materi yang berbeda, yang dapat mempengaruhi kemampuan pemecahan peserta didik. 


\section{DAFTAR PUSTAKA}

Anjani, A., Ratnamulyani, I.A., \& Kusumadinata,A A. (2018). Penggunaan Media Komunikasi Whatsapp terhadap Efektivitas Kinerja Karyawan. Jurnal Komunikasitio, 4(1).

Bafadhal, O.M (2018). Komunikasi Ritual Penggunaan Aplikasi WhatsApp: Studi Konsumsi Berita Lewat Group WhatsApp. Jurnal Komunikasi Indonesia, 49-56.

Dewi, A. S., Isnani, I., \& Ahmadi, A. (2019). Keefektifan Model Pembelajaran STAD Berbantuan Media Pembelajaran Terhadap Sikap dan Kemampuan Pemecahan Masalah Matematika. JIPMat, 4(1).

Dewi, W. A. F. (2020). Dampak Covid-19 terhadap implementasi pembelajaran daring di Sekolah Dasar. Edukatif:Jurnal IlmuPendidikan, 2(1), 55-61.

Effendi, L. A. (2012). Pembelajaran matematika dengan metode penemuan terbimbing untuk meningkatkan kemampuan representasi dan pemecahan masalah matematis siswa SMP. Jurnal Penelitian Pendidikan, 13(2), 1-10.

Hendriana, H., Rohaeti, E. E., \& Sumarmo, U. (2017). Hard Skills dan Soft Skills Matematik Siswa. Bandung: Refika Aditama.

Iskandar, R. (2020). Penggunaan Grup Whatsapp sebagai Media Pembelajaran terhadap Peserta Didik DTA At-Tawakal Kota Bandung. CommEdu (Community Education Journal), 3(2), 97-101.

Kuntarto,E (2017). Keefektifan Model Pembelajaran Daring dalam perkuliahan Bahasa Indonesia di Perguruan Tinggi . Indonesian Language Education and Literature 3(1),99-100.

Lestari, Kurnia E dan Mokhammad Ridwan Y. (2017). Penelitian Pendidikan Matematika. Bandung: Refika Aditama.

Ma'mun,A. T. (2015). Efektifitas Pembelajaran Bahasa Arab Melalui Media Sosial Whatsapp di Program BISA (Belajar Islam dan Bahasa Arab).

Matondang, Z. (2009). Validitas dan realibilitas suatu instrumen penelitian. Jurnal Tabularasa, 6(1), 87-97.

Pendidikan, K., \& Indonesia, K. R. (2016). KBBI daring. Diakses dari https://kbbi. kemdikbud. go. id/Cari/Index.(21 Juli 2020)

Pranajaya,P., \& Wicaksono, H. (2018). Pemanfaatan Aplikasi Whatsapp (WA) di Kalangan Pelajar : Studi Kasus di Mts Al Muddatsiriyah dan Mts Jakarta Pusat. Orbith: Majalah Ilmiah Pengembangan Rekayasa dan Sosial,14(1).

Retnawati, H. (2015). Analisis Kuantitatif Instrumen Penelitian. Yogyakarta: Parama Publishing

Pustikayasa, I. M. (2019). Grup WhatsApp Sebagai Media Pembelajaran. Widya Genitri :Jurnal IImiah Pendidikan, Agama Dan Kebudayaan Hindu, 10(2), 53-62. 
Sholikhakh, R. A., Pujiarto, H., \& Suwandono, S. (2019). Keefektifan Model Pembelajaran Problem Based Learning terhadap Minat dan Prestasi Belajar Matematika. Journal of Medives: Journal of Mathematics Education IKIP Veteran Semarang, 3(1), 33-39.

Sofyana, L., \& Rozaq, A. (2019). Pembelajaran Daring Kombinasi Berbasis Whatsapp pada Kelas Karyawan Prodi Teknik InformatikanUniversitas PGRI Madiun. Jurnal Nasional Pendidikan Teknik Informatika: JANAPATI,8(1), 81-86.

Utami, W. B., Sholikhah, Z., \& Kartana, T. J. (2018). Efektifitas Model Pembelajaran Open Ended terhadap Prestasi Belajar Matematika Ditinjau dari Kreativitas Siswa. Jurnal Edukasi dan Sains Matematika (JES-MAT), 4(1), 35-46.

Utomo,S. W., \& Ubaidillah, M. (2018). Pemanfaatan Aplikasi Whatsapp pada Pembelajaran Berbasis Masalah untuk Mata Kuliah Akuntansi Internasional di Universitas PGRI Madiun. Kwangsan, 6(2).

Widodo, S. A. (2015). Efektivitas pembelajaran team accelerated instruction terhadap kemampuan memecahkan masalah matematika siswa kelas VIII SMP Kota Jogjakarta.AdMathEdu, 5(2), 57298. 